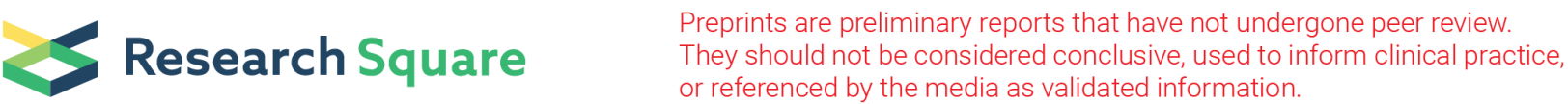

\section{Effects of polypropylene, polyvinyl chloride, polyethylene terephthalate, polyurethane, high- density polyethylene, and polystyrene microplastic on Nelumbo nucifera (Lotus) in water and sediment}

\section{Maranda Esterhuizen ( $\nabla$ maranda.esterhuizen@helsinki.fi )}

University of Helsinki: Helsingin Yliopisto https://orcid.org/0000-0002-2342-3941

Youngjun Kim

Korea Institute of Science and Technology Europe Forschungsgesellschaft mbH

\section{Research Article}

Keywords: Microplastics, oxidative stress, sediment, macrophyte, exposure, germination, seedling growth

Posted Date: May 11th, 2021

DOI: https://doi.org/10.21203/rs.3.rs-458889/v1

License: (c) (1) This work is licensed under a Creative Commons Attribution 4.0 International License.

Read Full License

Version of Record: A version of this preprint was published at Environmental Science and Pollution Research on October 20th, 2021. See the published version at https://doi.org/10.1007/s11356-02117033-0. 


\section{Abstract}

Plastic waste is recognised as hazardous, with the risk increasing as the polymers break down in nature to secondary microplastics or even nanoplastics. The number of studies reporting on the prevalence of microplastic in every perceivable niche and bioavailable to biota is dramatically increasing. Knowledge of

the ecotoxicology of microplastic is advancing as well; however, information regarding plants, specifically aquatic macrophytes, is still lacking. The present study aimed to gain more information on the ecotoxicological effects of six different polymer types as $4 \mathrm{~mm}$ microplastic on the morphology (germination and growth) and the physiology (catalase and glutathione S-transferase activity) of the rooted aquatic macrophyte, Nelumbo nucifera. The role of sediment was also considered by conducting all exposure both in a sediment-containing and sediment-free exposure system. Polyvinyl chloride and polyurethane exposures caused the highest inhibition of germination and growth compared to the control. However, the presence of sediment significantly decreased the adverse effects. Catalase activity was increased with exposure to polyvinyl chloride, polyurethane, and polystyrene, both in the presence and absence of sediment but more so in the sediment-free system. Glutathione S-transferase activity was significantly increased with exposure to polypropylene, polyvinyl chloride, and polyethylene terephthalate in the sediment-free system and exposure to polyethylene terephthalate and polyurethane in the absence of sediment. There was no clear correlation between the morphological and physiological effects observed. Further studies are required to understand the underlying toxicity mechanism of microplastics.

\section{Introduction}

The demand for plastics, as versatile polymers with multiple applications, has significantly increased over the years, with polypropylene (PP), polyethylene (PE), polystyrene (PS), polyvinylchloride (PVC), and polyethylene terephthalate (PET) being the major thermoplastics dominating the market (Lithner et al. 2011). In 2019, the global production of plastics reached 370 million tonnes (PlasticsEurope 2019). However, with the one-time-use attitude towards plastic items in conjunction with the current levels of plastic production and low recovery rate, hazardous plastic waste discarded into the environment is sure to increase (Dahlbo et al. 2018; van Velzen et al. 2019), posing a risk to the biota due to entanglement, suffocation or internal damage when consumed (Rochman et al. 2013; Naidoo et al. 2020).

Once discarded in nature, surface embrittled plastics are micro-cracked by climate conditions combined with microbial action resulting in their progressive degradation into the small fragments and particles known as microplastic (MP, particles smaller than $5 \mathrm{~mm}$ in size (Arthur et al. 2009)). The degradation may involve hydrolysis of ester bonds, photo-oxidation due to UV exposure, thermal degradation due to heat, and microbial degradation (da Costa et al. 2016; Luo et al. 2018; $\mathrm{Ng}$ et al. 2018). During manufacturing, some toxic compounds remain unpolymerised within the plastics. As the plastics degrade, these residual monomers are released into the environment (Revel et al. 2018). Chemicals reported to leach from plastics include bisphenol A, benzene, phthalates, and phenol (Wright and Kelly 2017), and further leaching of toxicants are facilitated by ester bonds hydrolysis (Lithner et al. 2011). 
MPs are being detected in nearly all ecosystems across the globe (Barnes et al. 2009; Lusher et al. 2015; da Costa et al. 2016; Imhof et al. 2017; Ng et al. 2018; Peeken et al. 2018; Scopetani et al. 2019), including the water column and sediments of many aquatic environments (Browne et al. 2010; Claessens et al. 2011; Naidoo et al. 2015; Reisser et al. 2015; Hoffman and Hittinger 2017). There is a consensus among the scientific community that even though plastic pollution in aquatic ecosystems is recognised as an environmental threat, data on the ecotoxicity of plastics are scarce (Eerkes-Medrano et al. 2015). Setälä et al. (2014) reported that MP could enter the food chain via ingestion and transferred from one trophic level to the next. Various severely toxic effects have been attributed to MP exposure as well as their leachates in different organisms tested (Pflugmacher et al. 2020a, 2021), but not all (Scopetani et al. 2020a). The presence of MPs also has been reported to disrupt the residence of natural biota and thus could potentially influence biodiversity (Pflugmacher et al. 2020b).

With the detection of MP in the water column (Reisser et al. 2015) and sediments (Scopetani et al. 2019) of aquatic environments, macrophytes are likely to be affected. The majority of the literature on the ecotoxicological impacts of MP has utilised animal systems, and reports on the effects in plants, especially aquatic macrophytes, despite their importance as primary producers in aquatic ecosystems, are limited (Yokota et al. 2017; van Weert et al. 2019). The present study aimed to gain more information on the ecotoxicological effects of different MP polymer types on the sediment-rooted aquatic macrophyte, Nelumbo nucifera (Lotus).

N. nucifera is India and Vietnam's national flower and plays a culturally significant role for China and Korea. Lotus flowers are commonly seen in water gardens globally as well as growing wildly in various freshwater habitats. Besides their aesthetic appeal, Lotus plants serve an important role in ecosystems by cooling water temperature and increasing the oxygen status due to leaf cover of the water surface. The plants also provide shelter for fish, protecting against avian predation (Kanabkaew and Puetpaiboon 2004). The potential of using Lotus in wastewater treatment has also been explored (Kanabkaew and Puetpaiboon 2004), especially for removing heavy metals and combatting eutrophication (Mishra 2009; Liu et al. 2013). Lotus plants have been cultured for over 2000 years for their substantial role as sustenance (Guo 2009; Escaray et al. 2012). The Lotus rhizome is consumed as a vegetable and is a source of flour. In many Asian countries and Korea, Lotus root tea or Lotus flower tea is consumed daily (Yu et al. 2002). Lotus seeds are edible and can be consumed fresh or processed into cakes, noodles, fermented rice wine, ice cream, and popcorn. The plants are also important as traditional medicines (Laongsri et al. 2009), as fresh Lotus seed wine has thirst-quenching, spleen healing, and anti-diarrheal properties (Wu et al. 2013). For the countries that cultivate Lotus on a large scale, the plants are an important export commodity.

The effects of the six most commonly utilised plastics, PP, PVC, polyurethane (PUR), PET, high-density polyethylene (HDPE), and expanded polystyrene (EPS), were assessed as MP (4 mm diameter particles) on the morphology (germination and growth) and physiology (antioxidative enzyme activities of catalase and glutathione S-transferase) of $N$. nucifera. The study did not intend to identify specific mechanisms of 
toxicity but to compare the toxicities of the six types of MP on one aquatic macrophyte species in terms of germination, growth, and antioxidative enzymes.

\section{Materials And Methods}

\subsection{Experimental materials}

PP MP was derived from the lids of TicTac boxes. Cable isolation was used to produce soft PVC MP, and yellow sponges were used as a source of PUR. From mineral water bottles and their caps, PET and HDPE MP, respectively, were produced. PS was obtained from expanded polystyrene (EPS) packaging. All materials were purchased from the local supermarket, cleaned and washed before shredding to MP on a desktop plastic recycler (SHR3D IT, 3devo B.V. Utrecht, Netherlands) with a sieve size of $4 \mathrm{~mm}$. Smaller particles were removed by manual sieving. Care was taken at all times to avoid self-contamination (Scopetani et al. 2020b).

Lotus seeds were purchased from BaiLing-Seeds (Yunhe Bailingguangao Sales Department, China). The lotus seeds were professionally opened by the supplier on one side to allow faster germination. Before the experiments' inception, the seeds were washed in water and imbibed for 24 hours. The lake sediment was collected from Lake Vesijärvi (Lahti, Finland) in 2018.

\subsection{Experimental setup}

The six treatment groups (one for each MP type) consisted of five replicates, each encompassing a beaker containing $1 \mathrm{~g}$ of the various types of MP, respectively, mixed into $5 \mathrm{~g}$ of lake sediment plus another $2 \mathrm{~g}$ of lake sediment on top (to avoid the MP washing out of the sediment) and $250 \mathrm{~mL}$ of standard medium ( $\mathrm{pH}$ 6.8). The standard medium consisted of $900 \mathrm{mg} / \mathrm{L} \mathrm{KNO}{ }_{3}, 900 \mathrm{mg} / \mathrm{L} \mathrm{Ca}\left(\mathrm{NO}_{3}\right)_{2}, 360$ $\mathrm{mg} / \mathrm{L} \mathrm{MgSO}_{4}, 200 \mathrm{mg} / \mathrm{L} \mathrm{KH}_{2} \mathrm{PO}_{4}, 40 \mathrm{mg} / \mathrm{L} \mathrm{Fe}-\mathrm{EDTA}$ and micronutrients: $1 \mathrm{mg} / \mathrm{L} \mathrm{MnSO}_{4}, 0.2 \mathrm{mg} / \mathrm{L} \mathrm{CuSO}_{4}$, $0.2 \mathrm{mg} / \mathrm{L} \mathrm{ZnSO}_{4}, 1.8 \mathrm{mg} / \mathrm{L} \mathrm{H}_{3} \mathrm{BO}_{3}, 3.4 \mathrm{mg} / \mathrm{L}(\mathrm{NH} 4)_{6} \mathrm{Mo}_{7} \mathrm{O}_{24}$, and $9 \mathrm{mg} / \mathrm{L} \mathrm{CoCl}_{2}$.

For the controls, MP was not added to the $7 \mathrm{~g}$ of sediment. A single previously imbibed lotus seed was embedded in the soil in replicates of five per treatment groups. The seeds were incubated at $24^{\circ} \mathrm{C} \pm 0.5^{\circ} \mathrm{C}$ and a light-dark cycle of 14:10 h (1500 lux) for seven days before assessing the germination, seedling growth and catalase and glutathione S-transferase enzyme activity. A second exposure was conducted exactly like the first; however, without sediment, i.e. $1 \mathrm{~g}$ of MP suspended in the standard medium.

\subsection{Morphological effects: Germination and growth}

After seven days, the seedlings were carefully removed from the sediment, and the roots were washed with water. The number of germinated seedlings were counted, and the length of each seedling was manually measured in centimetre $(\mathrm{cm})$ with a digital calliper.

Germinated seeds were defined operationally as having a radicle emergence length of $1 \mathrm{~mm}$. The final germination percentage (GP) were determined after seven days, according to the following formula: 


$$
G P=\frac{N g a t d a y 7}{N t} \times 100
$$

Where $\mathrm{Ng}$ is the number of germinated seeds, and $\mathrm{Nt}$ represents the total number of seeds used in the respective batch. The unit for GP is a percentage (\%) (Janssen 1973, Scott et al. 1984).

\subsection{Physiological effects: Catalase and glutathione S- transferase activity}

Enzyme extracts were prepared according to Stüven and Pflugmacher (2007) with minor amendments. Each seeding individually was ground to a fine powder in liquid nitrogen and suspended in $0.1 \mathrm{M}$ sodium phosphate buffer ( $\mathrm{pH}$ 6.5) containing $14 \mathrm{mM}$ dithioerythritol and $5 \mathrm{mM}$ EDTA. The solution was homogenised with a glass potter and stirred on ice for $30 \mathrm{~min}$ before centrifugation at $5000 \times \mathrm{g}$ for $5 \mathrm{~min}$ $\left(4^{\circ} \mathrm{C}\right)$. The soluble proteins were precipitated by ammonium sulphate ( $80 \%$ saturation). The soluble proteins were collected in the pellet of a second centrifugation step $\left(25000 \times \mathrm{g}, 30 \mathrm{~min}, 4^{\circ} \mathrm{C}\right)$. The pellet was dissolved in $20 \mathrm{mM}$ sodium phosphate buffer ( $\mathrm{pH}$ 7.0) and desalted on NAP-10 columns (Amersham Pharmacia, Uppsala, Sweden) before enzyme measurement.

Each replicates' protein content was determined (Bradford 1976) using the Bradford protein dye reagent (Sigma). Bovine serum albumin (98\%, Sigma) was used as a standard for the protein calibration of the assay method. A spectrophotometric assay was performed for the assessments of Catalase (CAT, EC 1.11.1.6) presented by Aebi et al. (1984) and expressed in SI units as $\mu \mathrm{kat} / \mathrm{mg}$ protein. The GST (EC 2.5.1.18) assay followed the conjugation rate of 1-chloro-2,4-dinitrobenzene (CDNB) with GSH at $340 \mathrm{~nm}$ (extinction coefficient $\mathbb{Q}=9.6 \mathrm{~L} / \mathrm{mmol} / \mathrm{cm}$ ) according to Habig et al. (1974).

\subsection{Statistical data treatment}

The data's homogeneity and normality were evaluated using IBM ${ }^{\circledR}$ SPSS ${ }^{\circledR}$ Statistics Version 25 (2018). Data were tested for normality and homogeneity. Based on the outcomes of these tests, the data were evaluated with the non-parametric Kruskal Wallis test, followed by a pair-wise comparison, to identify statistical significances between the treatment groups and controls. The a-value considered for significance was 0.05 after Bonferroni correction (Sokal and Rohlf 1997).

\section{Results And Discussion}

Lotus ( $N$. nucifera) plants, native to tropical Asia, grow in waterbodies not deeper than $1 \mathrm{~m}$, with a single flower and leaves on an erect peduncle protruding from a tuberous rhizome that grows in sediment (Imsabai et al. 2013). These lotus plants are at substantial risk of MP exposure in nature as MP has been detected in sediment from freshwater ecosystems (Klein et al. 2015; Scopetani et al. 2019). Additionally, during cultivation, plastic sheets supported by bamboo arches are used to cover the plants, which has been found to reduce the harvesting time and increase the yield, and plastic sheets are added under the sediments to avoid water and fertiliser losses (Guo et al. 2019). These plastic sheets are likely to degrade 
to MP in the sun with time, which could sediment to the rhizomes, especially after biofouling (Fazey and Ryan 2016; Kooi et al. 2017).

\subsection{Morphological effects}

The effects of the six MP types on the germination percentage of $N$. nucifera were tested both in the presence (Fig. 1A) and absence (Fig. 1B) of sediment. The MP particle size of $4 \mathrm{~mm}$ was selected to exclude seed pore blockage as the cause for the observed adverse effects (Bosker et al. 2019).

In both control groups, irrespective of the presence or absence of sediment, $100 \%$ of seeds sprouted after seven days. The overall pattern of the extent to which each MP type affected germination remained the same when comparing the two systems, both for germination (Fig. 1) and seedling growth (Fig. 3).

Considering the impact of the various polymer types of MP, the role of the sediment was evident as significantly more severe germination inhibition in the absence of sediment was observed after seven days ( $p<0.001$; Fig. 1). For example, PP caused no inhibitory effects in the presence of sediment ( $p=$ $0.154)$, but in the absence of sediment, the PP resulted in a $68 \%$ reduction in the germination percentage of the lotus seeds $(p=0.008)$. With PVC exposure, inhibition resulted both in the presence $(54 \% ; p=0.001)$ and absence $(76 \% ; p<0.001)$ of sediment, with the presence of sediment dampening the adverse effects on germination. In sediment, PUR caused 58\% inhibition $(p<0.001)$, whereas the inhibition was increased to $70 \%(p=0.004)$ in the absence of sediment. However, PET $(p=1)$, HDPE $(p=1)$ and PS $(p=0.390$ for sediment; $p=1$ for sediment free system) exposures did not influence the germination percentage of the lotus seeds in both systems. When ranking the various plastic types based on their inhibition of the germination percentage in the presence of sediment, the highest-ranked MP would be PUR, eliciting the most severe effects, followed by PVC, with PP, PS, HDPE, and PET eliciting no statistically significant adverse effects. In the absence of sediment, the following changes to the ranking occurred starting with PVC, PUR and PP, but HDPE, PS, and PET exposures did not hinder germination.

Figure 2. Number of germinated seeds over a period of seven days with exposure to seven types of microplastic against an unexposed control in A) sediment and B) a sediment-free system. Data points present the average number of germinated seeds \pm standard deviation $(n=5)$. Statistical significance $(p$ $\leq 0.05)$ compared to the control is presented by an asterisk (*).

After exposing pre-germinated Lotus seeds to MP in the presence and absence of sediment, all seedlings in all treatments were alive, and no severe chlorosis or other defects were observed except for reduced growth. As with the germination percentage findings, seedling length followed a similar pattern for both the effects of the plastic types and the presence and absence of sediment. The absence of sediment amplified the inhibition effects of the various plastic types compared to the exposure system containing sediment. In the sediment containing exposure system (Fig. 3A), the ranking of the MP types causing the most growth inhibition to the least (or no effect) were PUR (69.2\% inhibition, $p<0.001), P V C(59.4 \%, p<$ $0.001)$, PS (54.4\%, $p<0.001), \operatorname{HDPE}(26.1 \%, p<.0 .001), \operatorname{PP}(25.8 \%, p=0.001)$, and lastly PET, which caused no inhibition $(p=1)$. 
In the absence of sediment (Fig. 3B), the inhibition ranking was as follows, with highest inhibition calculated for PUR (83.0\%, $p<0.001)$, followed by PVC (76.2\%, $p<0.001)$, PP $(63.6 \%, p<0.001)$, PET $(47.9 \%, p<0.001), \operatorname{HDPE}(47.4 \%, p<0.001)$, and the lowest for PS $(44.7 \%, p<0.001)$.

In agreement with the present study's findings, Zimmermann et al. (2014) reported that extracts from PVC and PUR were the most toxic, whereas PET and HDPE caused little or no toxicity. They reported that the toxicities of low-density polyethylene (LDPE), PS, and PP varied.

In the present study, MPs were administered at a concentration of $142 \mathrm{~g} / \mathrm{kg}(\mathrm{w} / \mathrm{w})$ in the sediment containing system ( $14 \%$ sediment dry weight) or $4 \mathrm{~g} / \mathrm{L}$ in the sediment-free system. This concentration did not prove lethal to the Lotus seedlings as they continued to grow, albeit at a reduced rate. Van Weert et al. (2019) tested the effect of PS MP (20-500 $\mu \mathrm{m}$, up to $10 \%$ dry weight) and nanoplastic (50-190 nm, up to $3 \%$ sediment dry weight) on the growth of two sediment-rooted aquatic macrophytes, Myriophyllum spicatum and Elodea sp. for 21 days. Neither of the two macrophytes was significantly adversely affected by PS MP. However, for Lotus, the exposure concentration of $14 \%(w / w)$ PS MP caused a significant reduction in the seedlings' length.

Kalčíková et al. (2017) examined the effects of PE microbeads on the free-floating macrophyte Lemna minor. The microbeads did not affect growth or photosynthesis but resulted in root growth inhibition and damage to the root cells. In the present study, the germination of the Lotus seeds was not affected by HDPE, but the overall seedling length was reduced in sediment and sediment-free treatments.

\subsection{Physiological effects}

The physiological effects, measured as the effects on two antioxidative enzymes' activities, differed significantly from the morphological effects. In both the presence (Fig. 4A) and absence of sediment (Fig. 4B), only exposure to PVC (sediment $p<0.001$, sediment-free $p=0.037), P U R(p=0.050, p=0.001)$, and PS $(p=0.013, p=0.021)$ caused a significant increase in the CAT activity. PVC exposure caused the CAT activity in the lotus seedlings to increase by $63 \%$, both in the presence and absence of sediment. Exposure to PUR resulted in a $41 \%$ increase in the CAT activity in seedlings cultivated in sediment and a $66 \%$ increase in those cultivated in the sediment-free system. PS elevated the catalase activity of the seedlings in sediment by $42 \%$ and those in the sediment-free system by $50 \%$.

The GST activity of the seedling in sediment significantly increased by $50.8 \%$ with PP $(p=0.021)$, by $82.6 \%$ with PVC $(p<0.001)$, and by $50.3 \%$ with PET $(p=0.044)$ exposure (Fig. $5 A)$. However, for the exposure system lacking sediment, GST activities were only elevated in seedlings exposed to PET $(p=$ $0.020)$ and PUR $(p<0.001)$ by $63.3 \%$ and $88.2 \%$, respectively. Again, the seedlings in the sediment-free system showed a higher GST activity with MP exposure than the respective controls (Fig. 5B).

Oxidative stress plays a role in the toxicity of MP, but the exact mechanism is not fully understood (Hu and Palić 2020). MP causes reactive oxygen species (ROS) generation and accumulation, inducing the activities of the antioxidative defence enzymes (Jeong et al. 2016, 2017). However, whether oxidative stress is a consequence of MP toxicity or causes the ecotoxicity observed is unclear. In the present study, 
no correlation could be drawn between the inhibitions on the seed germination and growth and the activities of the two enzymes tested. For example, the dominant growth and germination inhibition compared to the control was observed with PUR and PVC exposure; however, PUR and PVC did not significantly affect the GST activity in the sediment containing or sediment-free exposures. Furthermore, PS exposure did not lead to significant growth or germination inhibition but resulted in a significant increase in CAT activity irrespective of the presence or absence of sediment. Also, PET exposure had no significant morphological adverse effects but elicited the GST activity compared to the control.

Plastics are considered biochemically inert (Hammer et al. 2012); however, in the environment, polymers are likely to degrade via biotic and abiotic processes (Lambert et al. 2014), releasing hazardous additives (Lithner et al. 2011). Nonetheless, after seven days of exposure, degradation is unlikely. Sub-micron sized or nanoparticle additives, which are not chemically bound to the polymer, are used in commercial thermoplastic applications more frequently (Sherman, 2012). As the additives are typically lipophilic, they can be transferred to fat in a relatively short time (Bieber et al. 1985). These compounds can penetrate cell membranes and interfere in biochemical reactions inducing toxic effects (Hammer et al. 2012). However, Fang (2012) commented that the internalisation of nanoparticles would be limited in plants due to protection provided by cell walls as a physical barrier.

In the study by van Weert et al. (2019), significant effects on the growth of M. spicatum and an Elodea sp. were not evident from PS MP exposure even with the highest exposure concentration of $10 \%$. The presented study aimed to compare the toxicities of various MP types; therefore, a higher concentration was selected to observe the differences in toxicities. Scopetani et al. (2019) reported an average MP concentration of $396 \mathrm{MP}$ particles/kg in sediment collected from Lake Vesijärvi (Lahti, Finland). Using the conversion presented by Besserling et al. (2018), i.e. using a weight of $5 \mu \mathrm{g} /$ particle, the concentration reported by Scopetani et al. (2019) amounts to $2 \mathrm{mg} / \mathrm{kg}$. Klein et al. (2015) reported MP concentrations of up to $1 \mathrm{~g} / \mathrm{kg}$ in sediment collected on the shore of the Rhine (Rhine-Main Area, Germany). In the freshwater environment, up to $2561 \mathrm{MP}$ particles $/ \mathrm{m}^{3}$ have been reported in lake water samples in Asia and Europe (Cera et al. 2020). Using the Besserling et al. (2018) conversion, this amounts to $12.8 \mu \mathrm{g} / \mathrm{L}$. In the current study, a concentration of $142 \mathrm{~g} / \mathrm{kg}(14 \%)$ was used in sediment and $4 \mathrm{~g} / \mathrm{L}$ in water. Therefore, even with the predicted future increase in environmental MP in mind, the results should not be used to evaluate ecotoxicological risk but to compare the effects elicited by the plastic types.

Considering the ecosystem services of Lotus in the aquatic environment of regulating the water temperature, oxygen status, and role in habitat structure and providing shelter, the morphological effects of the MP on germination and seedlings become significant. Reduced germination and plant growth brought about by MP exposure could thus negatively impact the hydrology of MP contamination aquatic ecosystems as well as the biodiversity. With Lotus contributing to the economy as an export commodity and food source, reduced yields due to MP exposure could also have secondary adverse effects.

\section{Conclusion}


The presented study aimed to fill in the knowledge gap regarding the toxicity of various polymer types of MPs on plants, specifically aquatic macrophytes. PUR and PVC caused the most significant inhibition of seed germination and seedling growth with no apparent correlation to the trends seen in the elicitation of antioxidative stress enzymes. The mechanistic toxicity of MP need to be tested against more macrophytes, as based on the current knowledge of three studies investigating the effects of MP on macrophytes, some effects could be species-specific. The exact mechanism of inhibition is not yet understood; however, based on the MP size used in the present study, the effects seen are unlikely due to uptake of the MP particles, and seven days of exposure is expectedly too short a period to induce leaching. However, nanoparticle additives not chemically bound to the polymer or unpolymerised residual monomers within the plastics are likely to be involved.

\section{Declarations}

\section{Ethics approval and consent to participate}

Not applicable.

\section{Consent for publication}

Not applicable.

\section{Availability of data and materials}

The datasets used and/or analysed during the current study are available from the corresponding author on reasonable request.

\section{Competing interests}

The authors declare that they have no competing interests

\section{Funding}

Funding was received from the National Research Council of Science \& Technology (NST) grant by the Korean government (MSIP) (No. CAP-17-01-KIST Europe). The University of Helsinki provided open access funding.

\section{Author contributions}

Conceptualisation: ME, YJK; Data curation: ME; Formal analysis: ME; Funding acquisition: ME, YJK; Investigation: ME, YJK; Methodology; ME; Project administration ME; Resources, ME; Writing - original draft: ME; Writing - review \& editing: ME, YJK.

\section{Acknowledgements}


We kindly acknowledge Prof Dr Pflugmacher (University of Manitoba) for helpful discussions. Funding was received from the National Research Council of Science \& Technology (NST) grant by the Korean government (MSIP) (No. CAP-17-01-KIST Europe). The University of Helsinki provided open access funding.

\section{References}

Aebi H (1984) Catalase in vitro. Methods Enzymol 105:121-6.

Arthur C, Baker J, Bamford H (2009) Proceedings of the international research workshop on the occurrence, effects and fate of microplastic marine debris. Sept 9-11, 2008, NOAA Technical Memorandum NOS-OR\&R30.

Barnes DKA, Galgani F, Thompson RC, Barlaz M (2009) Accumulation and fragmentation of plastic debris in global environments. Phil Trans R Soc B 364:1985-1998. https://doi.org/10.1098/rstb.2008.0205

Besseling E, Redondo-Hasselerharm P, Foekema EM, Koelmans AA (2019) Quantifying ecological risks of aquatic micro- and nanoplastic. Crit Rev Env Sci Tec 49:32-80.

https://doi.org/10.1080/10643389.2018.1531688

Bieber W-D, Figge K, Koch J (1985) Interaction between plastics packaging materials and foodstuffs with different fat content and fat release properties Food Addit Contam 2:113-124.

https://doi.org/10.1080/02652038509373533

Bosker T, Bouwman LJ, Brun NR, Behrens T, Vijver MG (2019) Microplastics accumulate on pores in seed capsule and delay germination and root growth of the terrestrial vascular plant Lepidium sativum.

Chemosphere 226:774-781. https://doi.org/10.1016/j.chemosphere.2019.03.163.

Bradford MM (1976) A rapid and sensitive method for the quantitation of microgram quantities of protein utilising the principle of protein-dye binding. Anal Biochem 72:248-254. https://doi.org/10.1016/00032697(76)90527-3

Browne MA, Galloway TS, Thompson RC (2010) Spatial patterns of plastic debris along estuarine shorelines. Environ Sci Technol 44:3404-3409. https://doi.org/10.1021/es903784e

Cera A, Cesarini G, Scalici M (2020) Microplastics in freshwater: Whati the news from the world? Diversity 12(7):276. https://doi.org/10.3390/d12070276

Claessens M, De Meester S, Van Landuyt L, De Clerck K, Janssen CR (2011) Occurrence and distribution of microplastics in marine sediments along the Belgian coast. Mar Pollut Bull 62:2199-2204. https://doi.org/10.1016/j.marpolbul.2011.06.030.

da Costa JP, Santos PSM, Duarte AC, Rocha-Santos T (2016) (Nano)plastics in the environment Sources, fates and effects. Sci Total Environ 566-567:15-26. 
https://doi.org/10.1016/j.scitotenv.2016.05.041.

Dahlbo H, Poliakova V, Mylläri V, Sahimaa O, Anderson R (2018) Recycling potential of post-consumer plastic packaging waste in Finland. Waste Manage 71:52-61.

https://doi.org/10.1016/j.wasman.2017.10.033.

Eerkes-Medrano D, Thompson RC, Aldridge DC (2015) Microplastics in freshwater systems: a review of the emerging threats, identification of knowledge gaps and prioritisation of research needs. Water Res 75:63-82. https://doi.org/10.1016/j.watres.2015.02.012.

Escaray FJ, Menendez AB, Gárriz A, Pieckenstain FL, Estrella MJ, Castagno LN, Carrasco P, Sanjuán J, Ruiz OA (2012) Ecological and agronomic importance of the plant genus Lotus. Its application in grassland sustainability and the amelioration of constrained and contaminated soils. Plant Sci 182:12133. https://doi.org/10.1016/j.plantsci.2011.03.016.

Fang IJ (2012) Cellular membrane trafficking of mesoporous silica nanoparticles. Doctoral Theses 12634, lowa State University. https://lib.dr.iastate.edu/etd/12634

Fazey FMC, Ryan PG (2016) Biofouling on buoyant marine plastics: an experimental study into the effect of size on surface longevity. Environ Pollut 210:354-360. https://doi.org/10.1016/j.envpol.2016.01.026

Guo HB (2009) Cultivation of lotus (Ne/umbo nucifera Gaertn. ssp. nucifera) and its utilization in China. Genet Resour Crop Evol 56:323-330. https://doi.org/10.1007/s10722-008-9366-2

Habig W, Pabst MJ, Jacoby WB (1974) Glutathione S-transferase: the first step in mercapturic acid formation. J Biol Chem 249:1730-1739.

Hammer J, Kraak MH, Parsons JR (2012) Plastics in the marine environment: the dark side of a modern gift. Rev Environ Contam Toxicol 220:1-44. https://doi.org/10.1007/978-1-4614-3414-6_1. PMID: 22610295.

Hoffman MJ, Hittinger E (2017) Inventory and transport of plastic debris in the Laurentian Great Lakes. Mar Pollut Bull 115:273-281. https://doi.org/10.1016/j.marpolbul.2016.11.061.

Hu M, Palić D (2020) Micro- and nano-plastics activation of oxidative and inflammatory adverse outcome pathways. Redox Biol 37:101620. https://doi.org/10.1016/j.redox.2020.101620.

Imhof HK, Sigl R, Brauer E, Feyl S, Giesemann P, Klink S, Leupolz K, Löder MGJ, Löschel LA, Missun J, Muszynski S, Ramsperger AFRM, Schrank I, Speck S, Steibl S, Trotter B, Winter I, Laforsch C (2017) Spatial and temporal variation of macro-, meso- and microplastic abundance on a remote coral island of the Maldives, Indian Ocean. Mar Pollut Bull 116:340-347.

https://doi.org/10.1016/j.marpolbul.2017.01.010. 
Imsabai W, Leethiti P, Netlak P, van Doorn WG (2013) Petal blackening and lack of bud opening in cut lotus flowers (Nelumbo nucifera): Role of adverse water relations. Postharvest Biol Technol 79:32-38. https://doi.org/10.1016/j.postharvbio.2012.12.017.

Janssen JGM (1973) A method of recording germination curves. Ann Bot 37:705-708.

Jeong CB, Kang HM, Lee MC et al (2017) Adverse effects of microplastics and oxidative stress-induced MAPK/Nrf2 pathway-mediated defense mechanisms in the marine copepod Paracyclopina nana. Sci Rep 7:41323. https://doi.org/10.1038/srep41323

Jeong CB, Won EJ, Kang HM, Lee MC, Hwang DS, Hwang UK, Zhou B, Souissi S, Lee SJ, Lee JS (2016) Microplastic size-dependent toxicity, oxidative stress induction, and p-JNK and p-p38 activation in the monogonont rotifer (Brachionus koreanus). Environ Sci Technol 50(16):8849-8857. https://doi.org/10.1021/acs.est.6b01441

Kalčíková G, Gotvajn AZ, Kladnik A, Jemec A (2017) Impact of polyethylene microbeads on the floating freshwater plant duckweed Lemna minor. Environ Pollut 230:1108-1115.

https://doi.org/10.1016/j.envpol.2017.07.050.

Kanabkaew T, Puetpaiboon U (2004) Aquatic plants for domestic wastewater Treatment: Lotus (Nelumbo nucifera) and Hydrilla (Hydrilla verticillata) systems. Songklanakarin J Sci Technol 26:749-756.

Klein S, Worch E, Knepper TP (2015) Occurrence and spatial distribution of microplastics in river shore sediments of the Rhine-Main area in Germany. Environ Sci Technol 49(10):6070-6076.

https://doi.org/10.1021/acs.est.5b00492

Kooi M, Van Nes EH, Scheffer M, Koelmans AA (2017) Ups and downs in the ocean: effects of biofouling on vertical transport of microplastics. Environ Sci Technol 51:7963-7971.

https://doi.org/10.1021/acs.est.6b04702

La-ongsri W, Trisonthi C, Balslev H (2009) Management and use of Nelumbo nucifera Gaertn. in Thai wetlands. Wetlands Ecol Manage 17:279-289. https://doi.org/10.1007/s11273-008-9106-6

Lambert S, Sinclair C, Boxall A (2014) Occurrence, degradation, and effect of polymer-based materials in the environment. Rev Environ Contam Toxicol 227:1-53. https://doi.org/10.1007/978-3-319-01327-5_1

Lithner D, Larsson A, Dave G (2011) Environmental and health hazard ranking and assessment of plastic polymers based on chemical composition. Sci Total Environ 409:3309-24.

https://doi.org/10.1016/j.scitotenv.2011.04.038.

Liu C, Yang J, Ma X, Liu L, Wang Y, Shu J (2013) Ecological restoration using Trapa bispinosa and Nelumbo nucifera on eutrophic water body in Baizangdian Lake. Wetl Sci 11(4):510-514. 
Luo Q, Liu Z, Yin H, Dang Z, Wu P, Zhu N, Lin Z, Liu Y (2018) Migration and potential risk of trace phthalates in bottled water: A global situation. Water Res 147:362-372.

https://doi.org/10.1016/j.watres.2018.10.002.

Lusher A, Tirelli V, O'Connor I et al (2015) Microplastics in Arctic polar waters: the first reported values of particles in surface and sub-surface samples. Sci Rep 5:14947. https://doi.org/10.1038/srep14947

Mishra V (2009) Accumulation of cadmium and copper from aqueous solutions using Indian Lotus (Nelumbo nucifera). AMBIO: A Journal of the Human Environment 38 (2):110-112. https://doi.org/10.1579/0044-7447-38.2.110.

Naidoo T, Glassom D, Smit AJ (2015) Plastic pollution in five urban estuaries of KwaZulu-Natal, South Africa. Mar Pollut Bull 101:473-480. https://doi.org/10.1016/j.marpolbul.2015.09.044.

Naidoo T, Rajkaran A, Sershen (2020) Impacts of plastic debris on biota and implications for human health: A South African perspective. S Afr J Sci 116(5/6):7693. https://doi.org/10.17159/sajs.2020/7693

$\mathrm{Ng} \mathrm{E}$, Lwanga EH, Eldridge SM, Johnston P, Hu H, Geissen V, Chen D (2018) An overview of microplastic and nanoplastic pollution in agroecosystems. Sci Total Environ 627:1377-1388.

https://doi.org/10.1016/j.scitotenv.2018.01.341.

PlasticsEurope (2019) Plastics - the Facts 2020 An analysis of European plastics production, demand and waste data. https://www.plasticseurope.org/download_file/force/4261/181

Peeken I, Primpke S, Beyer B et al (2018) Arctic sea ice is an important temporal sink and means of transport for microplastic. Nat Commun 9:1505. https://doi.org/10.1038/s41467-018-03825-5

Pflugmacher S, Sulek A, Mader H, Heo J, Noh JH, Penttinen OP, Kim Y, Kim S, Esterhuizen M (2020a) The influence of new and artificial aged microplastic and leachates on the germination of Lepidium sativum L. Plants 9:339. https://doi.org/10.3390/plants9030339

Pflugmacher S, Huttunen JH, Wolff MV, Penttinen OP, Kim YJ, Kim S, Mitrovic SM, Esterhuizen-Londt M (2020b) Enchytraeus crypticus avoid soil spiked with microplastic. Toxics 8(1):10. https://doi.org/10.3390/toxics8010010

Reisser J, Slat B, Noble K, du Plessis K, Epp M, Proietti M, de Sonneville J, Becker T, Pattiaratchi C (2015) The vertical distribution of buoyant plastics at sea: an observational study in the North Atlantic Gyre. Biogeosciences 12:1249-1256. https://doi.org/10.5194/bg-12-1249-2015.

Revel M, Châtel A, Mouneyrac C (2018) Micro(nano)plastics: A threat to human health? Curr Opin Environ Sci Health 1:17-23. https://doi.org/10.1016/j.coesh.2017.10.003.

Rochman C, Browne M, Halpern B et al (2013) Classify plastic waste as hazardous. Nature 494:169-171. https://doi.org/10.1038/494169a 
Scopetani C, Chelazzi D, Cincinelli A, Esterhuizen-Londt M (2019) Assessment of microplastic pollution: occurrence and characterisation in Vesijärvi lake and Pikku Vesijärvi pond, Finland. Environ Monit Assess 191:652. https://doi.org/10.1007/s10661-019-7843-z

Scopetani C, Esterhuizen M, Cincinelli A, Pflugmacher S (2020a) Microplastics exposure causes negligible effects on the oxidative response enzymes glutathione reductase and peroxidase in the oligochaete Tubifex tubifex. Toxics 8:14. https://doi.org/10.3390/toxics8010014

Scopetani C, Esterhuizen-Londt M, Chelazzi D, Cincinelli A, Setälä H, Pflugmacher S (2020b) Selfcontamination from clothing in microplastics research. Ecotoxicol Environ Saf 189:110036. https://doi.org/10.1016/j.ecoenv.2019.110036.

Scott SJ, Jones RA, Williams WA (1984) Review of data analysis for seed germination. Crop Sci 24:1192-1199. https://doi.org/10.2135/cropsci1984.0011183X002400060043x

Setälä O, Fleming-Lehtinen V, Lehtiniemi M (2014) Ingestion and transfer of microplastics in the planktonic food web. Environ Pollut 185:77-83. https://doi.org/10.1016/j.envpol.2013.10.013.

Sherman LM (2012) Sub-Micron additives make strides (just don't say 'Nano'). Plastics Technology (Plast Technol) 58:26-27,30-31. https://www.ptonline.com/articles/sub-micron-additives-make-strides-just-dontsay-nano

Sokal RR, Rohlf FJ (1997) Biometry. The Principles and Practice of Statistic in Biological, Research. WH Freeman and Company, New York.

Stüven J, Pflugmacher S (2007) Antioxidative stress response of Lepidium sativum due to exposure to cyanobacterial secondary metabolites. Toxicon 50:85-93. https://doi.org/10.1016/j.toxicon.2007.02.019

van Velzen EUT, Brouwer MT, Feil A (2019) Collection behaviour of lightweight packaging waste by individual households and implications for the analysis of collection schemes. Waste Manage 89:284293. https://doi.org/10.1016/j.wasman.2019.04.021.

van Weert S, Redondo-Hasselerharm PE, Diepens NJ, Koelmans AA (2019) Effects of nanoplastics and microplastics on the growth of sediment-rooted macrophytes. Sci Total Environ 654:1040-1047. https://doi.org/10.1016/j.scitotenv.2018.11.183.

Wright SL, Kelly FJ (2017) Plastic and human health: A micro issue? Environ Sci Technol 51:6634-6647. https://doi.org/10.1021/acs.est.7b00423

Wu C, Xia Y, Tang X (2013) Optimisation of fermentation process for lotus rice-wine production by response surface methodology. Mod Food Sci Technol 29:1675-1679.

Yokota K, Waterfield H, Hastings C, Davidson E, Kwietniewski E, Wells B (2017) Finding the missing piece of the aquatic plastic pollution puzzle: interaction between primary producers and microplastics. Limnol 
Oceanogr Lett 2:91-104. https://doi.org/10.1002/lol2.10040.

Yu X, Lan B, Zhang J, Zhang W (2002) Progress in the research on post-harvest physiology and storage techniques of Nelumbo nucifera gaertn [J]. Guangzhou Food Sci Technol 3:019.

Zimmermann L, Dierkes G, Ternes TA, Völker C, Wagner M (2019) Benchmarking the in vitro toxicity and chemical composition of plastic consumer products. Environ Sci Technol 53(19):11467-11477. https://doi.org/10.1021/acs.est.9b02293

\section{Figures}




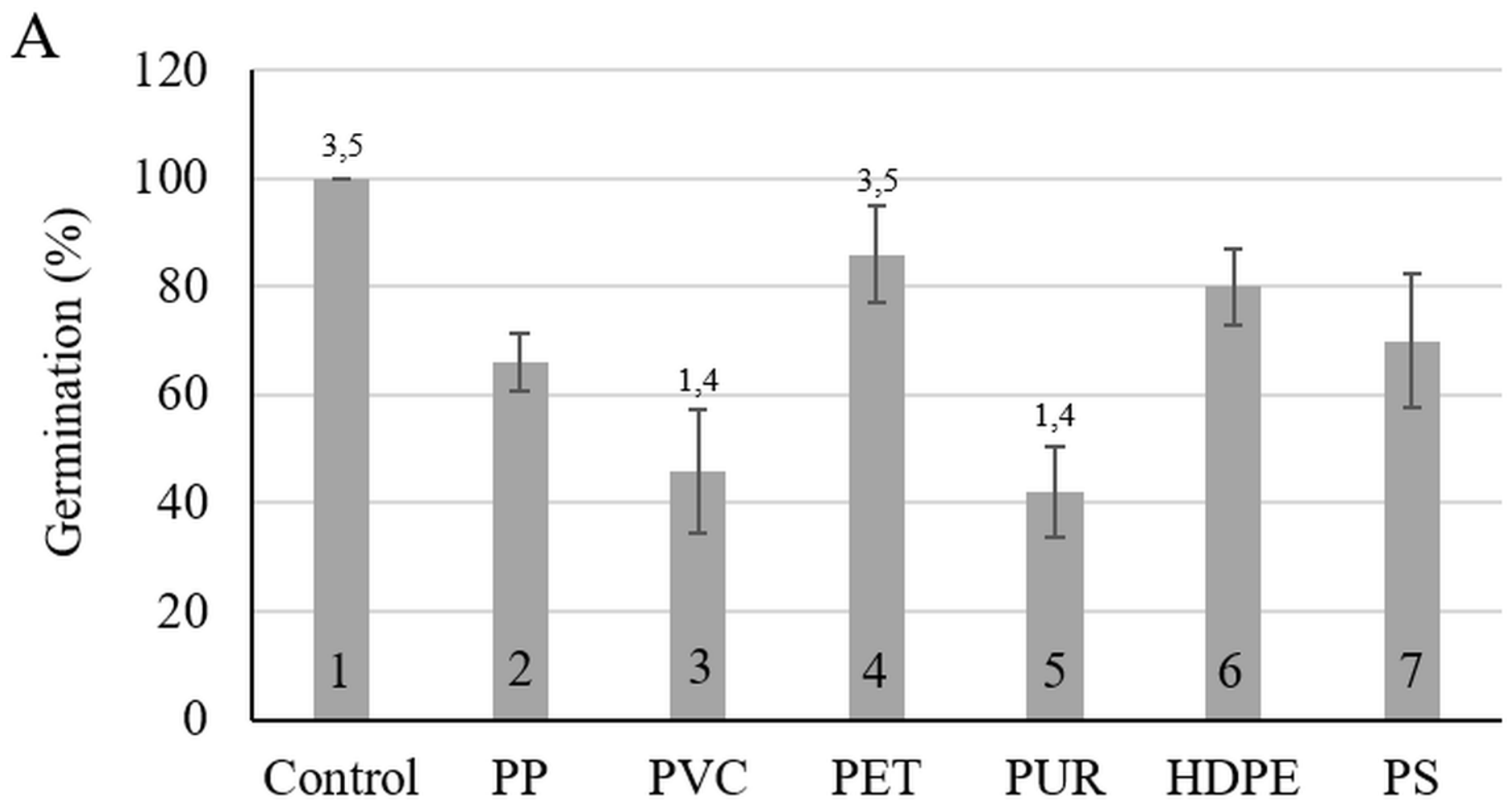

B

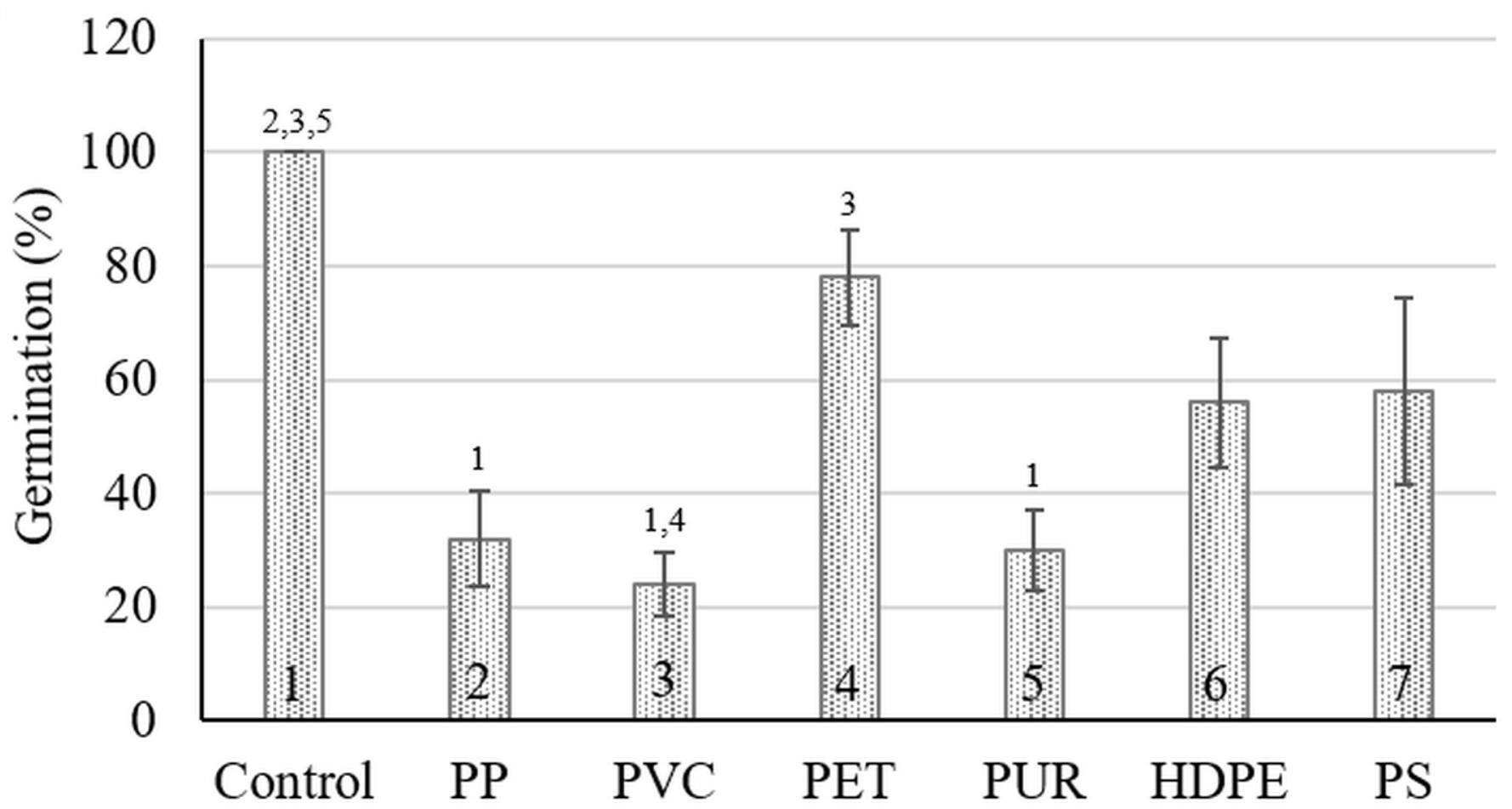

Figure 1

Germination percentage of Nelumbo nucifera seeds after seven days of exposure to six types of microplastic particles in A) sediment and B) a sediment-free system. Bars present average germination percentage \pm standard deviation $(n=5)$. Numbers above the bars indicate statistical significance $(p \leq$ 0.05) compared to 1: control, 2: polypropylene, 3: polyvinyl chloride, 4: Polyethylene terephthalate, 5: polyurethane, 6: high-density polyethylene, 7: polystyrene 
A

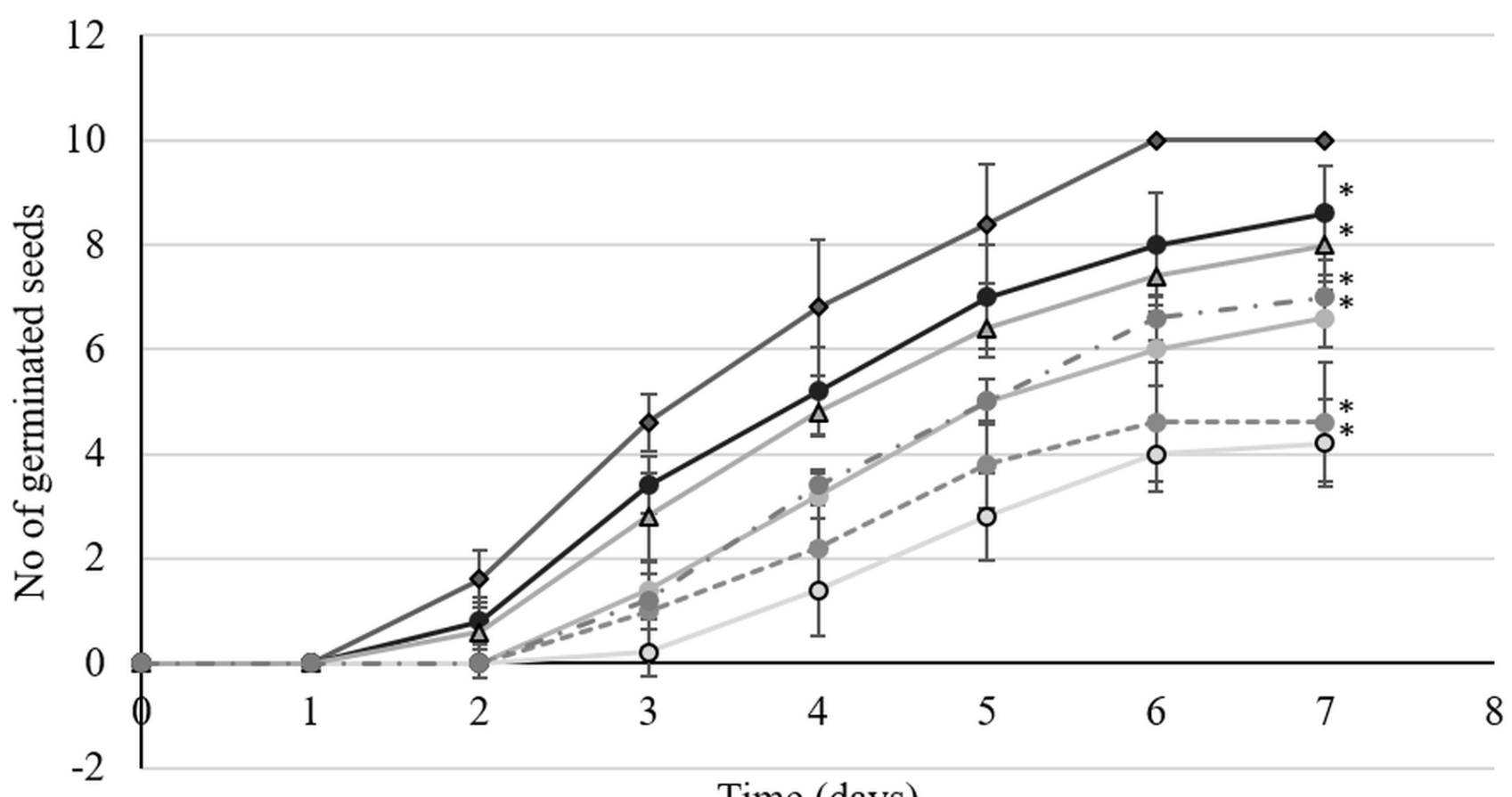

B

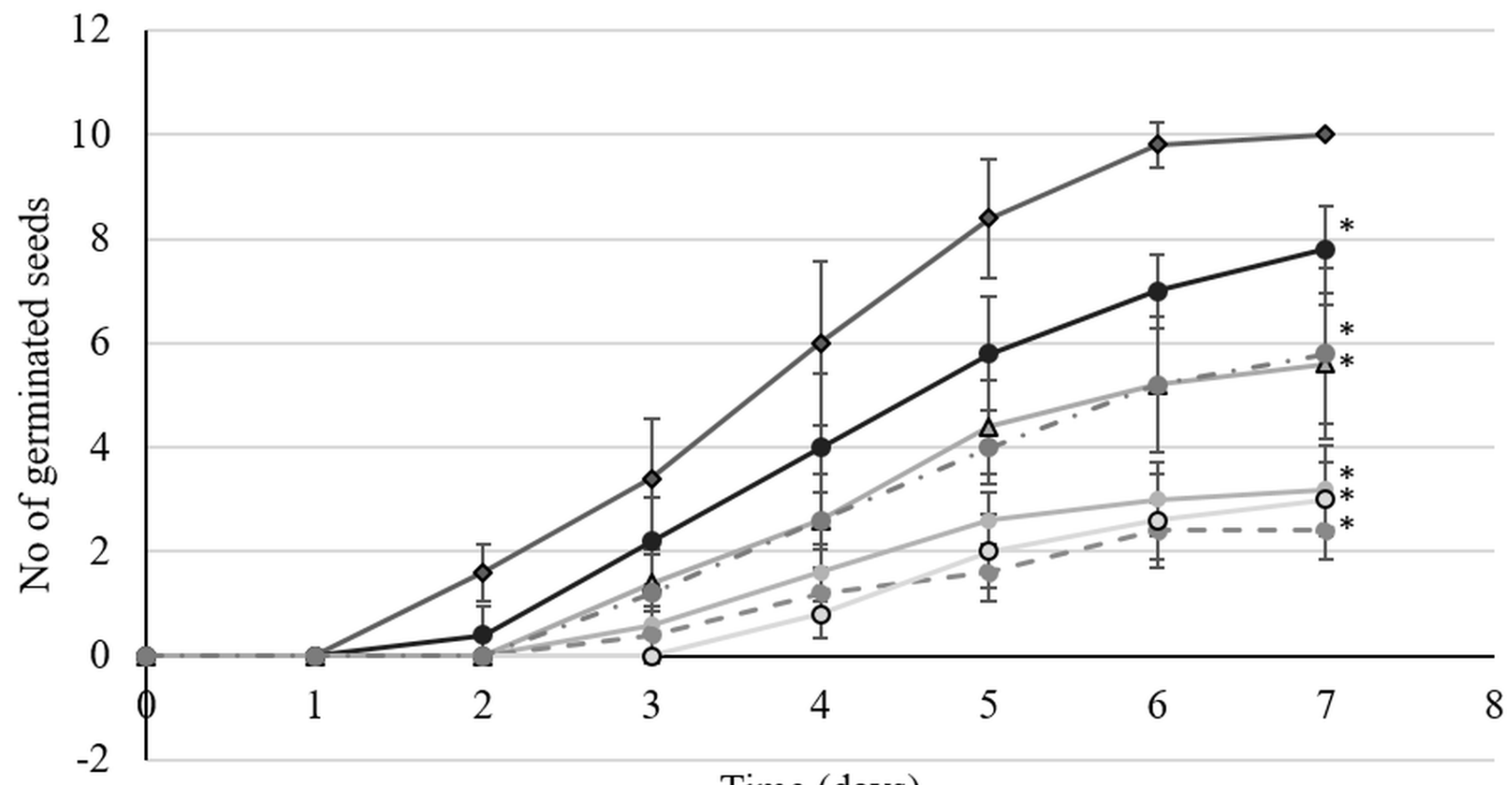

Time (days)

$\leadsto$ Control $\rightarrow$ PP $-\rightarrow$ PVC $\rightarrow$ PET $\multimap$ PUR $\triangle$ HDPE $-\bullet$ PS

\section{Figure 2}

Number of germinated seeds over a period of seven days with exposure to seven types of microplastic against an unexposed control in A) sediment and B) a sediment-free system. Data points present the average number of germinated seeds \pm standard deviation $(n=5)$. Statistical significance $(p \leq 0.05)$ compared to the control is presented by an asterisk $(*)$. 

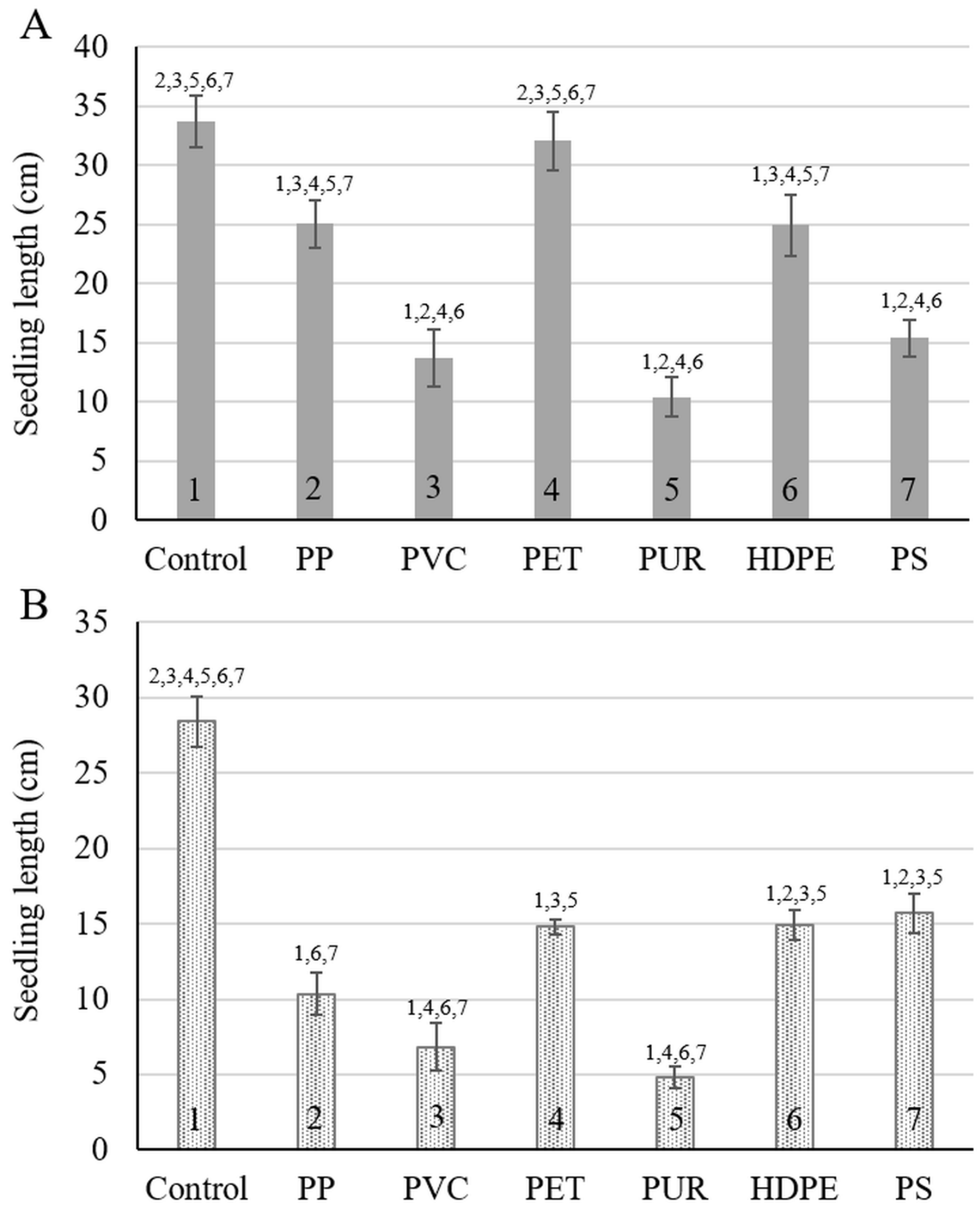

Figure 3

The length of the Nelumbo nucifera seedlings after seven days of exposure to six types of microplastic particles in A) sediment and B) a sediment-free system. Bars present average seedling length \pm standard deviation $(n=5)$. Numbers above the bars indicate statistical significance $(p \leq 0.05)$ compared to 1 : control, 2: polypropylene, 3: polyvinyl chloride, 4: Polyethylene terephthalate, 5: polyurethane, 6: highdensity polyethylene, 7: polystyrene 


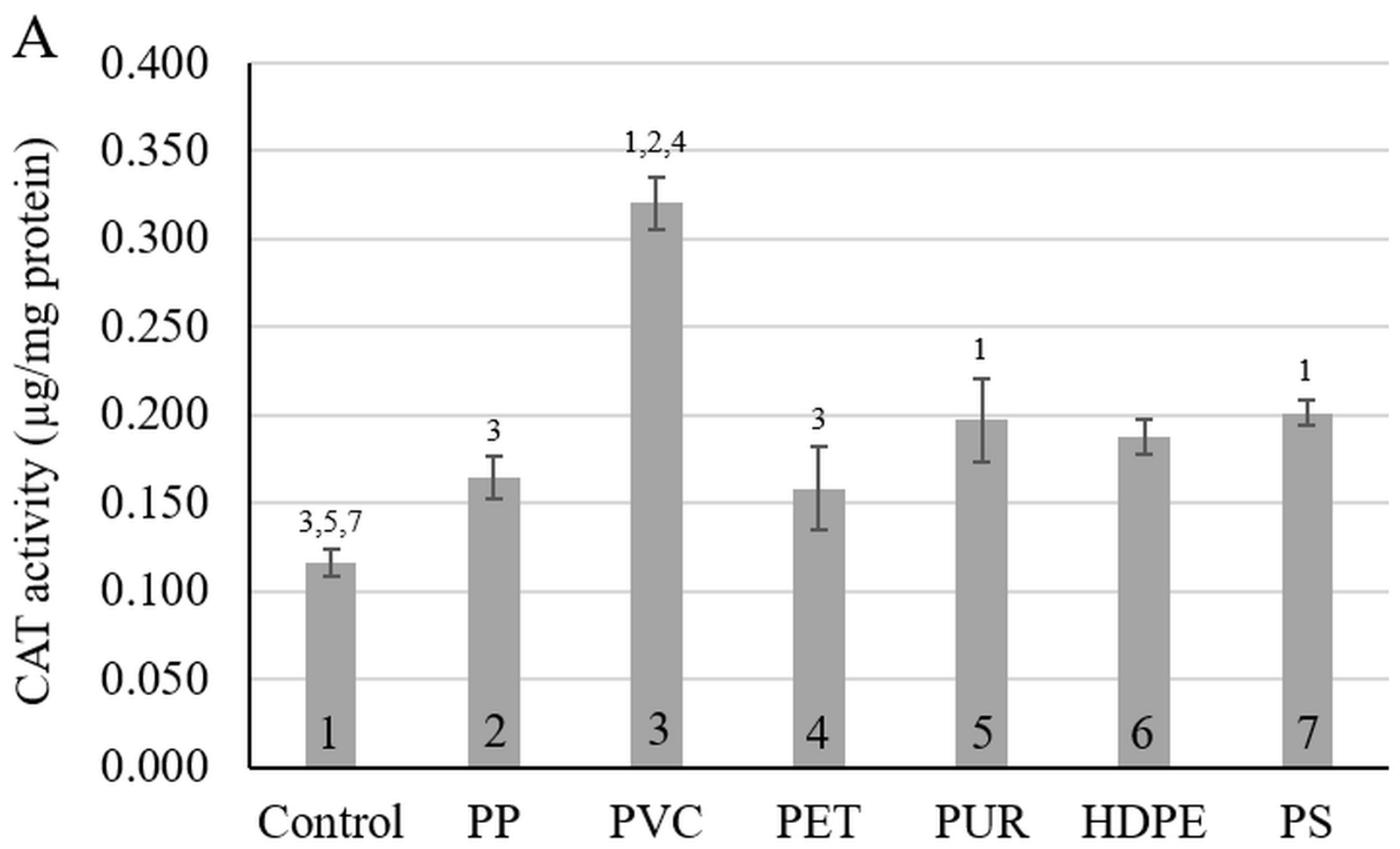

$\mathrm{B}$

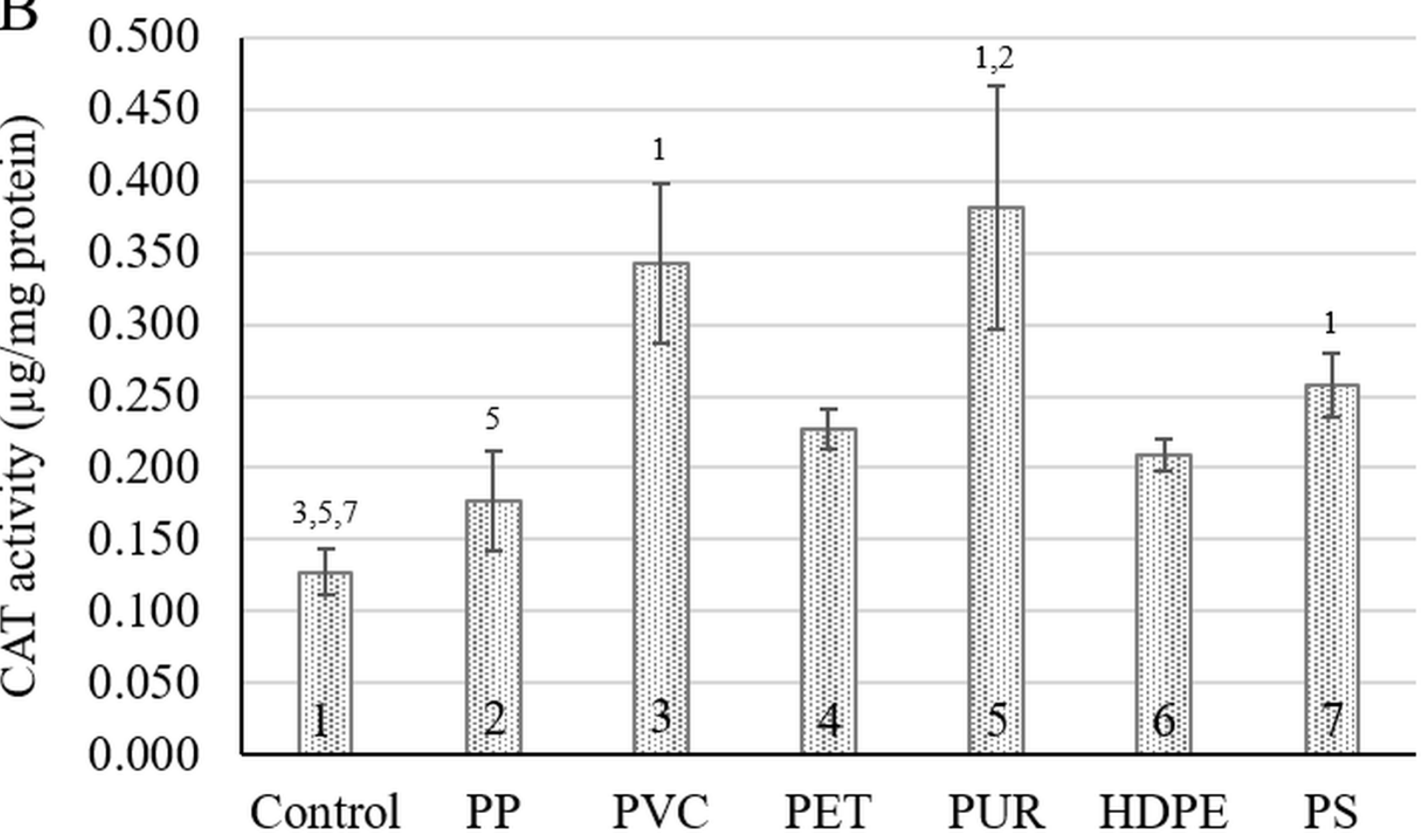

Figure 4

Nelumbo nucifera seedlings' catalase activity after seven days of exposure to six types of microplastic particles in A) sediment and B) a sediment-free system. Bars present average CAT activity \pm standard deviation $(n=5)$. Numbers above the bars indicate statistical significance $(p \leq 0.05)$ of each treatment compared to 1: control, 2: polypropylene, 3: polyvinyl chloride, 4: Polyethylene terephthalate, 5: polyurethane, 6: high-density polyethylene, 7: polystyrene 


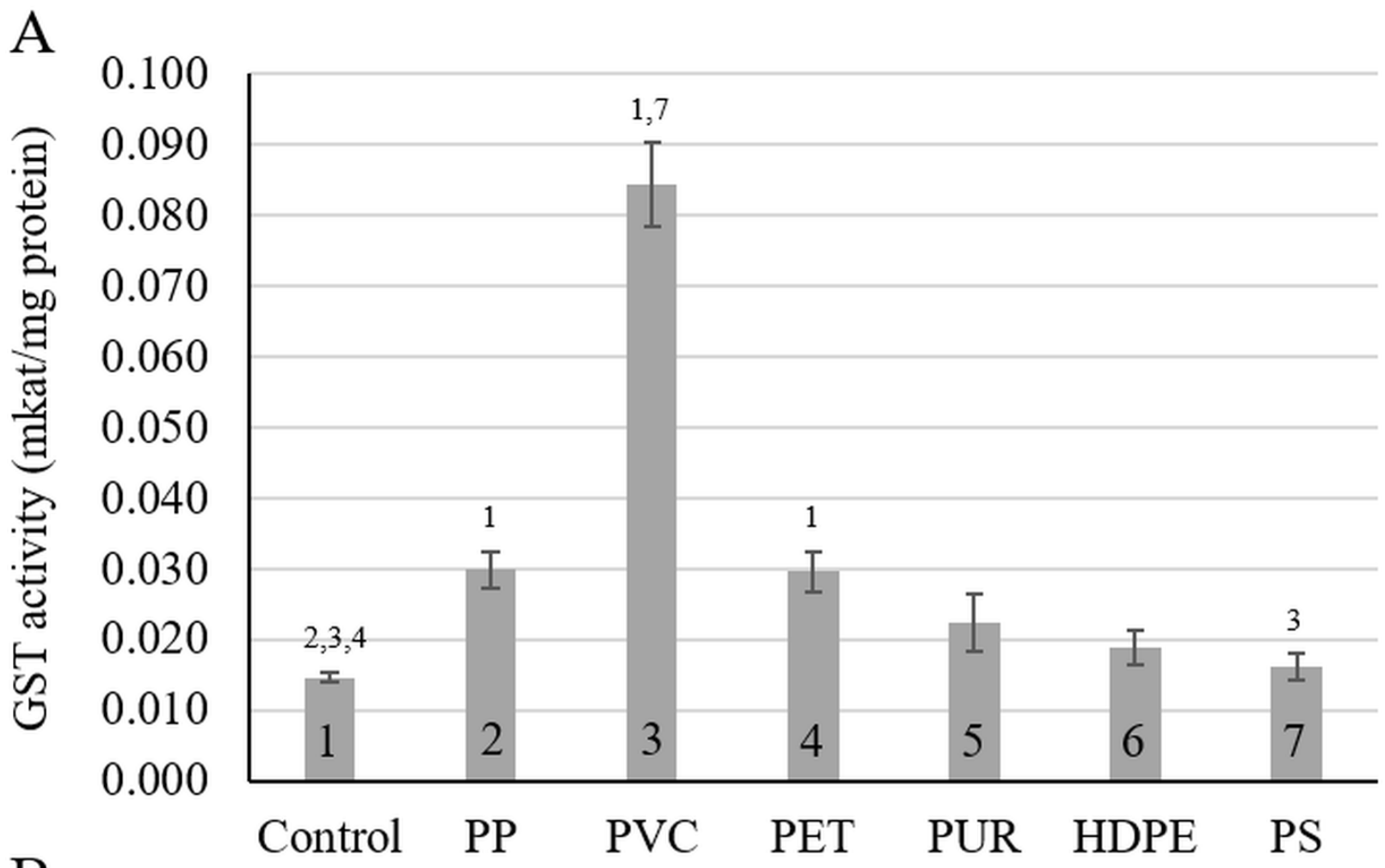

B

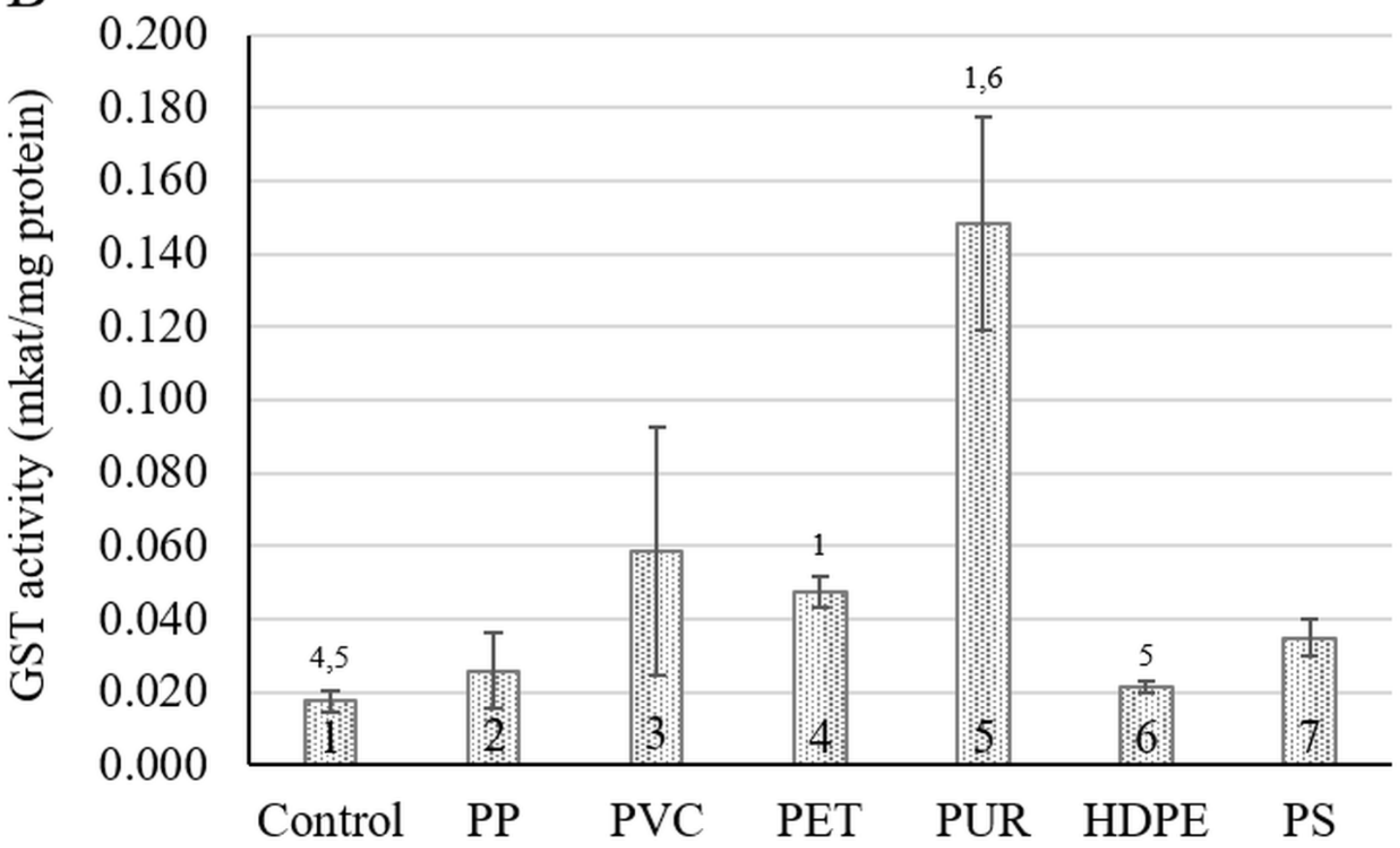

Figure 5

Glutathione S-transferase activity in Nelumbo nucifera seedlings after seven days of exposure to six types of microplastic particles in A) sediment and B) a sediment-free system. Bars present average GST activity \pm standard deviation $(n=5)$. Numbers above the bars indicate statistical significance $(p \leq 0.05)$ compared to 1: control, 2: polypropylene, 3: polyvinyl chloride, 4: Polyethylene terephthalate, 5 : polyurethane, 6: high-density polyethylene, 7: polystyrene 